Original Research Article

\title{
Evaluation of teaching methodologies in pharmacology for undergraduates: a cross-sectional analysis in a medical college of South India
}

\author{
Zainab Ghazala*, Prakash Kalshetty, Shrenik Vardhamane
}

\begin{abstract}
Department of Pharmacology, Khaja Bandanawaz Institute of Medical Sciences, Kalaburagi, Karnataka, India
\end{abstract}

Received: 12 January 2019 Accepted: 17 January 2019

\section{*Correspondence to: Dr. Zainab Ghazala, Email: zainab.ghazala@ gmail.com}

Copyright: () the author(s), publisher and licensee Medip Academy. This is an openaccess article distributed under the terms of the Creative Commons Attribution NonCommercial License, which permits unrestricted noncommercial use, distribution, and reproduction in any medium, provided the original work is properly cited.

\begin{abstract}
Background: Pharmacology is an important part of medical education. A competent doctor should be able to prescribe rational treatment to the patients to minimise the adverse effects and contribute to the improvement of overall healthcare system. There is a dire need to reform the undergraduate pharmacology curriculum to match up to the rapidly evolving medical field. Feedback system is one of the most successful instruments in improving any system. We have undertaken a similar feedback system to study the advantages and disadvantages of various study methods for teaching theory and practical exercises to the medical undergraduates.

Methods: This is a cross sectional questionnaire based study conducted in the department of pharmacology. Students of MBBS 2nd year were enrolled into the study. The purpose of the study was explained to them and clarifications were made if any. The questionnaire included questions on various aspects of teaching methodology and graded by students on internationally accepted 'Likert' scale.

Results: In our study students favoured teaching by blackboard method (96\%) and many preferred a combination of blackboard and power point presentation. Discussing on issues of clinical significance of the topic was favoured by $96 \%$ of the students and $67 \%$ students responded that stressing on the facts concerned with Post graduate entrance exams is more important. Sixty nine percent and $85 \%$ students preferred short essays and MCQs respectively as method of evaluation and $68 \%$ of them favoured evaluation by both the methods. Regarding pharmacology practical exercises most of the students preferred clinical problems, dosage calculation, ADR reporting and other problem based learning techniques. Studying pharmacology as an integrated subject with other clinical subjects was preferred by $68 \%$ of the students.

Conclusions: It is well known that students learn better when they are involved actively in learning process than when they are passive recipients. In our study we realised that undergraduate pharmacology teaching pattern should be modified mostly towards pharmacotherapeutics and clinical pharmacology.
\end{abstract}

Keywords: Evaluation, Feedback, Pharmacology, Teaching methods

\section{INTRODUCTION}

Pharmacology is an important part of medical education. A competent doctor should be able to prescribe rational treatment to the patients to minimise the adverse effects and contribute to the improvement of overall healthcare system. Pharmacology course prepares the students to deal with the pharmacotherapeutic aspect of various diseases and to utilise p-drug concept and list of essential medicines prepared from time to time during the clinical practice. ${ }^{1}$ Dispensing pharmacy and animal experiments have been the cornerstone of traditional pharmacology practical exercises but the clinical utility and relevance of these exercises have always been questioned and criticized. ${ }^{2}$ Time and again MCI has amended regulations that teaching methods should be student centric and comprise 
a wholesome curriculum to address various learning aspects of medical undergraduates with modern educational technologies. ${ }^{3}$ Presently teaching of theory aspect of pharmacology is limited to lecture classes and tutorials with very few seminars. While practical exercises consist mainly of pharmacy preperations, chemical testing of unknown compound and rabbit eye experiments which are not done now other include study of some standard fixed drug combinations, dosage calculations, studying prototype clinical scenarios which are old and less relevant to the present clinical practice. Looking at present scenario there is a dire need to reform undergraduate pharmacology curriculum to match up to the rapidly evolving medical field. While theory classes are now being largely taken through power point presentations, the practical exercises need to be more relevant to the clinical practice. Feedback system is one of the most successful instruments in improving any system. Authors have undertaken a similar feedback system to study the advantages and disadvantages of various study methods for teaching theory and practical exercises to the medical undergraduates.

\section{METHODS}

The present study was a cross sectional questionnairebased study conducted in the department of pharmacology KBNIMS, Kalaburagi, Karnataka after taking approval from the Institutional Ethics Committee. The questionnaire was pretested in 10 students before the start of study and final questionnaire was prepared after removing ambiguous questions.

\section{Inclusion criteria}

Students of MBBS $2^{\text {nd }}$ professional year who attended at least two academic terms of pharmacology classes were included into the study after they agreed to sign the written informed consent form to participate in the study.

\section{Exclusion criteria}

Students who attended less than the above said number of classes, students who were absent on the day when study was conducted were excluded from the study.

The study was conducted in the Department of Pharmacology of authors college. Students were asked to assemble in the lecture hall and instructions were given to them regarding filling of questionnaire and grading of Likert's scale. The purpose of the study was explained to them and clarifications were made if any. Time period of 30 minutes was given to them to fill the forms. The questionnaire consisted of two parts. First part included questions on the internationally accepted 'Likert' scale and participants were asked to indicate the degree to which they agreed with each statement on a Likert scale ranging from 1 to 5 ( $1=$ strongly disagree to $5=$ strongly agree $)$. The second part included replying with 'Yes' or 'No' (Annexure 1) followed by an open-ended question about satisfaction quotient with present teaching methods and any relevant suggestion for improvement or any reform required (Annexure 2).

\section{RESULTS}

A total 110 students were enrolled, out of which 100 successfully completed questionnaire were considered to be included in the study. Analysis was done on median score and percentage wise distribution of the various parameters used in the questionnaire. Table1 shows the questionnaire and the response of students on Likert's scale.

Among the responders $96 \%$ favoured teaching by blackboard method while $67 \%$ students preferred teaching by a combination of both the methods, $53 \%$ students disapproved the use of LCD projectors. Seventy six percent students mostly preferred lecture classes as a teaching method while $49 \%$ preferred tutorial classes. Students also showed interest in group discussions (69\%) and seminars (59\%). Forty eight percent students disagreed that lecture classes should be decreased and $41 \%$ wanted an increase in the number of lectures, $59 \%$ and $79 \%$ students favoured conducting more of seminars and group discussions respectively. Content of the lecture was important for $75 \%$ of students while $90 \%$ students felt that holding the students' attention during the class was most important. Discussing on issues of clinical significance of the topic was favoured by $96 \%$ of the students and $67 \%$ students responded that stressing on the facts concerned with post graduate entrance exams is more important. Seventy nine percent students were of the opinion that each section should be taught by single teacher completely and only $22 \%$ students favoured that it should be taught by different teachers. Regarding the method of evaluation $58 \%$ students did not favour writing long essays. While $69 \%$ and $85 \%$ students preferred short essays and MCQs as method of evaluation and $68 \%$ of them favoured evaluation by both the methods. Regarding preference of pharmacology practical exercises, $65 \%$ did not prefer to do pharmacy experiments, $40 \%$ students agreed to include CAL in the practical exercises where as $40 \%$ students disapproved of CAL. Clinical problems were favoured by $82 \%$ students while $78 \%$ and $82 \%$ students felt that dosage calculations and ADR reporting respectively should also be included in practical exercises. Studying pharmacology as an integrated subject with other clinical subjects was preferred by $68 \%$ of the students.

Regarding the conduct of classes (Annexure 1) $71 \%$ students replied that teachers give them enough opportunity to clarify their doubts, $63 \%$ felt that lectures were not well structured, $60 \%$ agreed that continuity was maintained between individual lectures adequately, and $68 \%$ students told that important points were not summarized at the end of presentation. In open ended question (Annexure 2) most of the students opined that they expect many changes in the teaching methodologies and the method of evaluation and assessment in pharmacology. 
Few opined that they do not find pharmacy preparations useful during clinical postings. Rather they were interested in presenting clinical case scenarios and discussing about that during pharmacology classes.

Table 1: Questionnaire with response on Likert's scale.

\begin{tabular}{|c|c|c|c|c|c|c|}
\hline Question & Options & $\begin{array}{l}\text { Strongly } \\
\text { disagree }(\%)\end{array}$ & $\begin{array}{l}\text { Disagree } \\
(\%)\end{array}$ & $\begin{array}{l}\text { Undecided } \\
(\%)\end{array}$ & $\begin{array}{l}\text { Agree } \\
(\%)\end{array}$ & $\begin{array}{l}\text { Strongly } \\
\text { agree }(\%)\end{array}$ \\
\hline \multirow{3}{*}{$\begin{array}{l}\text { Which medium of } \\
\text { teaching you feel is } \\
\text { better? }\end{array}$} & Black board teaching & 0 & 2 & 2 & 15 & 81 \\
\hline & Power point presentation & 24 & 27 & 25 & 20 & 4 \\
\hline & Both & 4 & 13 & 16 & 35 & 32 \\
\hline \multirow{4}{*}{$\begin{array}{l}\text { Which method of } \\
\text { teaching you feel is } \\
\text { better? }\end{array}$} & Lecture class & 4 & 6 & 14 & 39 & 37 \\
\hline & Tutorials & 10 & 12 & 29 & 42 & 7 \\
\hline & Group discussion & 4 & 8 & 19 & 39 & 30 \\
\hline & Seminars & 6 & 19 & 16 & 56 & 3 \\
\hline \multirow{4}{*}{$\begin{array}{l}\text { Do you feel the } \\
\text { following reforms } \\
\text { should be made? }\end{array}$} & $\begin{array}{l}\text { Decrease the number of } \\
\text { lectures }\end{array}$ & 14 & 34 & 24 & 20 & 8 \\
\hline & $\begin{array}{l}\text { Increase the number of } \\
\text { lectures }\end{array}$ & 12 & 20 & 27 & 32 & 9 \\
\hline & Include more student seminars & 8 & 11 & 22 & 42 & 17 \\
\hline & Include more group discussion & 3 & 5 & 13 & 46 & 33 \\
\hline \multirow{4}{*}{$\begin{array}{l}\text { Which factors you } \\
\text { think are most } \\
\text { appropriate for } \\
\text { evaluating a teachers } \\
\text { teaching ability? }\end{array}$} & Content of the lecture & 5 & 8 & 12 & 51 & 24 \\
\hline & Hold students attention & 2 & 4 & 4 & 28 & 62 \\
\hline & $\begin{array}{l}\text { Stress on issues of clinical } \\
\text { significance }\end{array}$ & 2 & 0 & 2 & 42 & 54 \\
\hline & $\begin{array}{l}\text { Stress on facts of importance } \\
\text { in pg entrance exams }\end{array}$ & 4 & 5 & 24 & 34 & 33 \\
\hline \multirow{2}{*}{$\begin{array}{l}\text { You think you will } \\
\text { learn better if each } \\
\text { section is }\end{array}$} & $\begin{array}{l}\text { Completely taught by single } \\
\text { teacher }\end{array}$ & 3 & 9 & 9 & 32 & 47 \\
\hline & $\begin{array}{l}\text { Divided into different topics } \\
\text { taught by different teachers }\end{array}$ & 20 & 34 & 24 & 14 & 8 \\
\hline \multirow{4}{*}{$\begin{array}{l}\text { Regarding pattern of } \\
\text { evaluation, which } \\
\text { method you feel is a } \\
\text { better way of } \\
\text { evaluation? }\end{array}$} & Long essay questions & 25 & 33 & 23 & 14 & 5 \\
\hline & Short essay questions & 8 & 6 & 17 & 46 & 23 \\
\hline & MCQs & 2 & 9 & 4 & 31 & 54 \\
\hline & Combination of the above & 6 & 6 & 20 & 37 & 31 \\
\hline \multirow{6}{*}{$\begin{array}{l}\text { What is your } \\
\text { preference for } \\
\text { pharmacology } \\
\text { practical exercises? }\end{array}$} & Dispensing pharmacy & 20 & 45 & 8 & 20 & 7 \\
\hline & Animal experiment & 7 & 8 & 15 & 45 & 20 \\
\hline & $\begin{array}{l}\text { Computer assisted learning } \\
\text { (CAL) }\end{array}$ & 10 & 30 & 20 & 29 & 11 \\
\hline & Clinical problems & 4 & 8 & 6 & 65 & 17 \\
\hline & $\begin{array}{l}\text { Pharmacokinetic / dosage } \\
\text { calculations }\end{array}$ & 7 & 10 & 5 & 55 & 23 \\
\hline & $\begin{array}{l}\text { Pharmacovigilance (ADR } \\
\text { reporting) }\end{array}$ & 3 & 5 & 10 & 71 & 11 \\
\hline $\begin{array}{l}\text { Pharmacology is } \\
\text { better studied as an } \\
\text { integrated subject } \\
\text { with other clinical } \\
\text { subjects }\end{array}$ & 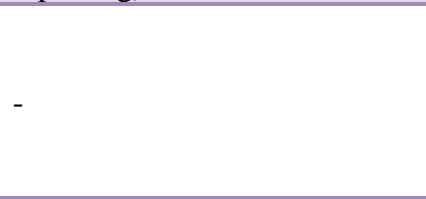 & 5 & 9 & 18 & 45 & 23 \\
\hline
\end{tabular}

\section{DISCUSSION}

Evaluation is a systematic process that consists of finding out the extent to which educational objectives have been achieved by the students which can provide the teachers with useful feedback information, obtained through informal mutual communication or preferably by a designed questionnaire., ${ }^{4,5}$ Various teaching methods have been developed for benefit of the students where involvement of students improves learning and thereby their performance in university examinations. ${ }^{6}$ While conducting this survey we realised that it is very important 
to review the teaching programs from time to time and make adequate modifications to keep pace with the progress in the subject and medical field as a whole. In the present study many interesting and important facts have come to light. A large proportion of students favoured black board teaching, and many opted for combination of black board /power point presentation. This correlates partially with the study done by Bhowmick $\mathrm{K}$ et al, in which participants suggested that teaching should be done by both black board and audiovisual aids. ${ }^{7}$ Disapproving PowerPoint presentation as a mode of teaching could be due to its irrational and ineffective use by the faculty. The lectures in many forms is the most commonly used method for transferring information in medical education and in our study participants opined about the effectives of this mode as preferred one. However, there are serious questions regarding the effectives of the traditional lecture approach as academic physicians often are not trained in giving effective lectures. Lecturing is frequently a one way process unaccompanied by discussion, questioning or immediate practice, which makes it a poor teaching method. In fact, lack of interaction is considered one of the major limitations of the traditional lecture method. Furthermore, when students have copies of lecture notes or a text, a significant percentage would prefer reading them rather than attending classes that offer little or no interaction. ${ }^{8}$ Because of above limitations, many students vouched for interactive teaching sessions in the form of tutorials, group discussion and seminars where learning is enhanced through effective use of key teaching skills including questioning, demonstrating, providing positive reinforcement and reviewing. Group discussion helps to gauge whether the candidate has certain personality traits and skills like ability to work in a team, verbal communication skills, reasoning ability, leadership skill, initiative, assertiveness, flexibility, creativity, team work, decision making ability, that is desired in its members. A huge number of students wanted to stress on issues of clinical significance as suggested by a study by Advani UP et al, that more than $50 \%$ of them want clinically oriented lecture and many students wanted more stress on facts that were important for the postgraduate entrance exams. ${ }^{9}$ Students by and large were of the opinion that long essays should be done away with and more and more short essays, short answers and MCQs should be considered for the purpose of evaluation. In our study we observed that most of the students are interested in pharmacology practical exercises that were clinically oriented such as clinical problems, dosage calculations and ADR reporting. It was also noted that the theory classes needed to be more structured and syllabus classified meticulously among various staff members for student's benefit. Medical education teachers need to be well trained to undertake well planned classes and assessments for the students which can ultimately bring out their best performance. Medical Council of India (MCI) has time and again put emphasis on integration of pharmacology with relevant clinical subjects. ${ }^{10}$ Usefulness of this has been demonstrated in various studies where authors opined that this integration provides students an opportunity to get acquainted with various diseases and learn role of different drugs simultaneously. ${ }^{11,12}$ There should be an emphasis on reinforcement of prescribing principles which are taught in pharmacology in clinical setups also, so that the future prescribers can follow good clinical practices. In our study also, students stressed upon having multiple sessions of integrated pharmacology to cover most of the common clinical conditions. It has also been confirmed in various studies that problem based learning (PBL) strengthens student's approach to self-directed learning and motivates them toward lifelong learning process. ${ }^{13}$

Limitations of the study included that it was conducted only in one batch and among the students who were present on the day of feedback evaluation. Students were given limited amount of time of half an hour to complete the feedback form which might have not been sufficient for some students.

\section{CONCLUSION}

It is accepted that reviewing the teaching and evaluation methods by feedback from students and modification of methodologies is very important for undergraduate pharmacology teaching as it is an ever changing subject and such attempts have been made all over India. The student's feedback serves as an array of effective methodologies in pharmacology teaching as it is well known that students learn better when they are involved actively in learning process than when they are passive recipients. Authors also realised that undergraduate pharmacology teaching pattern should be modified mostly towards Pharmacotherapeutics and clinical pharmacology. Indian medical curriculum should include more of elearning modules such as CAL for animal experiments.

\section{ACKNOWLEDGEMENTS}

Authors would like to thank the Dean of the college, students of MBBS $2^{\text {nd }}$ professional year, Head of the Department, all teaching and non teaching staff of department of pharmacology, KBNIMS for extending their support in smooth conduct of the study.

Funding: No funding sources

Conflict of interest: None declared

Ethical approval: The study was approved by the Institutional Ethics Committee

\section{REFERENCES}

1. Vasundara K, Kanchan P, Pundarikaksha HP, Girish $\mathrm{K}$, Prassana S, Jyothi R. An imperative need to change pharmacology curriculum: A pilot survey. Indian $\mathbf{J}$ Pharmacol. 2010 Dec;42(6):420.

2. Desai M. Changing face of pharmacology practicals for medical undergraduates. Indian J Pharmacol. 2009 Aug;41(4):151.

3. Regulations on Graduate Medical Education, MCI. New Delhi; 2012. Available at: 
https://www.mciindia.org/CMS/rules-

regulations/graduate-medical-education-regulations1997.

4. Gitanjali B. New wine in new bottle. Indian J Pharmacol. 2004 Mar 1;36(2):63.

5. Bhavsar VH, Vajpeyee SK, Joshi NJ, Mistry SD, Kantharia ND, Sharma AK, et al. Training during practical pharmacology sessions for undergraduate medical students: An experience with a modified teaching programme. Indian J Pharmacol. 1999 May 1;31(3):176.

6. Kaufman DM, Mann KV. Achievement of students in a conventional and problem-based learning (PBL) curriculum. Advances Health Sci Education. 1999 Nov 1;4(3):245-60.

7. Bhowmick K, Mukhopadhyay M, Chakraborty S, Sen PK, Chakraborty I. Assessment of perception of first professional MBBS students in India about a teaching learning activity in Biochemistry. South East Asian J Med Education. 2009;3(2):27-34.

8. Edlich RF. My last lecture. J Emergency Med. 1993;11(6):771-4.

9. Advani UP, Bhojani KG, Gada VP. VMGMC students view on the prevailing teaching methods in pharmacology and changes recommended. Solapur Med J. 2006;2:1-8.
10. Kela AK, Mehta VL. Impact of inclusion of clinical projects in undergraduate teaching. Indian $\mathrm{J}$ Pharmacol. 1993 Oct 1;25(4):249.

11. Han WH, Maxwell SR. Are medical students adequately trained to prescribe at the point of graduation? Views of first year foundation doctors. Scott Med J. 2006;51:27-32.

12. Shenfield GM. Integrating clinical pharmacology teaching with general practice. Br J Clin Pharmacol. 1998 Apr;45(4):399-401.

13. Michel MC, Bischoff A, zu Heringdorf D, Neumann D, Jakobs KH. Problem-vs. lecture-based pharmacology teaching in a German medical school. Naunyn-Schmiedeberg's Arch Pharmacol. 2002 Jul 1;366(1):64-8.

Cite this article as: Ghazala $\mathrm{Z}$, Kalshetty $\mathrm{P}$, Vardhamane S. Evaluation of teaching methodologies in pharmacology for undergraduates: a cross-sectional analysis in a medical college of South India. Int J Basic Clin Pharmacol 2019;8:18792. 
ANNEXURE 1: Questions with reply as 'YES' OR 'NO'.

\begin{tabular}{|c|c|c|c|}
\hline Sr. no. & Question & Yes & No \\
\hline 1 & Do your teachers give enough opportunity to clarify you doubts? & 71 & 29 \\
\hline 2 & Are the topics of lectures arranged in logical sequences well suited to your understanding? & 37 & 63 \\
\hline 3 & Do you think continuity between individual lectures is maintained adequately? & 60 & 40 \\
\hline 4 & Are the most important points summarized at the end of presentation? & 32 & 68 \\
\hline
\end{tabular}

ANNEXURE 2: Open ended question.

How satisfied are you with present teaching methods in pharmacology and any relevant suggestions for improvement? 